\title{
Pharmacognostic Evaluation of Bitter Melon from Brazilian Northeast (Momordica charantia L.): Identification of Momordicin II
}

\author{
William Antonio Sagástegui Guarniz*, Lídia Audrey Rocha Valadas, Karine Lima Silva, Karla Do Nascimento Magalhães, Raimundo Braz \\ Filho, Patrícia Georgina Garcia do Nascimento, Mírian Parente Monteiro, Mary Anne Medeiros Bandeira \\ Development of Drugs, Dentistry and Nursing College, Federal University of Ceara, Fortaleza, CE, BRAZIL.
}

\begin{abstract}
Objectives: To perform a pharmacognostic evaluation of bitter melon from Brazilian northeast (Momordica charantia L.) Methods: The botanical materials used consisted of leaves of Momordica charantia L., microcarpa and macrocarpa varieties collected in the period of flowering and fruiting. For the collection of the leaves was used pruning shears and for herborization were followed the usual procedures in this type of collection. The studies were carried out with the fresh leaves of these two varieties of Momordica charantia $L$ to do the macro and micro morphological analysis. Results: the micro morphological analysis showed that the main differential parameter is that in the macrocarpa variety the trichomes are less frequent and are of the short multicellular type with 3 to 5 cells, whereas the microcarpa variety the trichomes are of the long multicellular type with 7 to 11 cells. The phytochemical approach has shown that the two varieties have in common alkaloids, steroids, triterpenoids, flavonoids, saponins, phenolic compounds, condensed tannins and flavonoids. Conclusion: Momordicin II
\end{abstract}

$\left(\mathrm{C}_{36} \mathrm{H}_{58} \mathrm{O}_{9}\right)$ was isolated and identified in the microcarpa variety by means of ${ }^{1} \mathrm{H}-\mathrm{NMR}$ and ${ }^{13} \mathrm{C}-\mathrm{NMR}$ and $2 \mathrm{D}$ structure similar to that found in the variety of Asian origin.

Key words: Momordica charantia, Pharmacognostic, Momordicin II

Natural Products, Pharmacognosy.

Correspondence

Dr. William Antonio Sagástegui Guarniz,

Development of Drugs, Pharmacy, Dentistry and Nursing College, Federal University of Ceara, 1210 Capitao Francisco Pedro, Fortaleza-60430370, CE, BRAZIL.

Phone: +55 8533668000

Email: williamantoniosag@gmail.com

DOI: 10.5530/jyp.2019.11.75

\section{INTRODUCTION}

In Brazil, Momordica charantia L. from the family Curcubitaceae, is a climbing plant found with wide frequency covering fences and shrubs along the paths from north to south of the country, especially after the rainy season. The plant is easily recognized for its multipart leaves, small isolated yellow flowers and fusiform fruits of 4 to $5 \mathrm{~cm}$, which, when ripe, open exposing seeds coated with a red aryl light, very sought after by birds and children and its foliage is highly estimated in the rural population due to the efficacy of the homemade preparations used against ectoparasites of man and animals, in the form of baths and compresses. It is a species native to Africa that was introduced in South America in the colonial period through the trafficking of black slaves brought from that continent, especially in the Northeast of Brazil. ${ }^{1}$ Twelve varieties of this species are known, two of which are distinguished mainly by the size of the fruits. A short fruit, 3-7 cm in length, designated as microcarpa variety whose occurrence is most common in South America, popularly known as melão-de-são-caetano and the long fruit, $14-15 \mathrm{~cm}$ in length, referred to as the macrocarpa that occurs most commonly in Asia where it is designated by the names of Balsam pear, Bitter cucumber, Bitter gourd, Foo gwa, Karela, La-kwa and used as edible and medicinal, ${ }^{2,3}$ (Figure 1).

The growing number of year-to-year research on this species demonstrates the great interest aroused by its pharmacological and chemical studies among researchers, ${ }^{4-15}$ for example.

Among the various constituents identified in the leaves, we can highlight as characteristic of $M$. charantia the momordicines I, II and III. The structures of the momordicines I and II were elucidated as $3 \beta, 7 \beta, 23]$ trihydroxycucurbita-5, 24-dien-19-al and its 23-O- $\beta$ - glucopyranoside, respectively. The momordicine III was isolated as acetate of $23-\mathrm{O}-\beta$ glucopyranoside of $3 \beta, 7 \beta, 23$ ]- trihydroxy-24-oxo-cucurbita-5,25-dien19-al. The mixture of these three components is called curcubitacin. ${ }^{16}$

In these works, the origin of the plant studied is not informed, although it can be deduced, with some degree of security, by the names of the authors, titles of the periodicals and countries where the research was carried out. It was thus verified that the great majority of the studies was developed with plants collected in Asia, that is, with great probability of being of the macrocarpa variety. Few are the works about the constituents and the pharmacological properties of the microcarpa variety of South America. The introduction of the Asian macrocarpa variety in the Horticulture of Medicinal Plants Prof. Francisco José de Abreu Matos from the Federal University of Ceara was given by the referred professor, when receiving a copy of the fruit of Altamira-Pará-Brazil, with the information that native Indians of the region were using the fruits as food, from cultivation coming from seeds provided by Japanese visitors, which served as a stimulus for the more detailed study of the microcarpa variety, as well as to determine pharmacognostic parameters between these two varieties, now presented, allowing its comparison with the data recorded in the literature.

\section{MATERIALS AND METHODS}

\section{Botanical materials}

The botanical materials used consisted of leaves of Momordica charantia L., microcarpa and macrocarpa varieties collected from specimens of the 


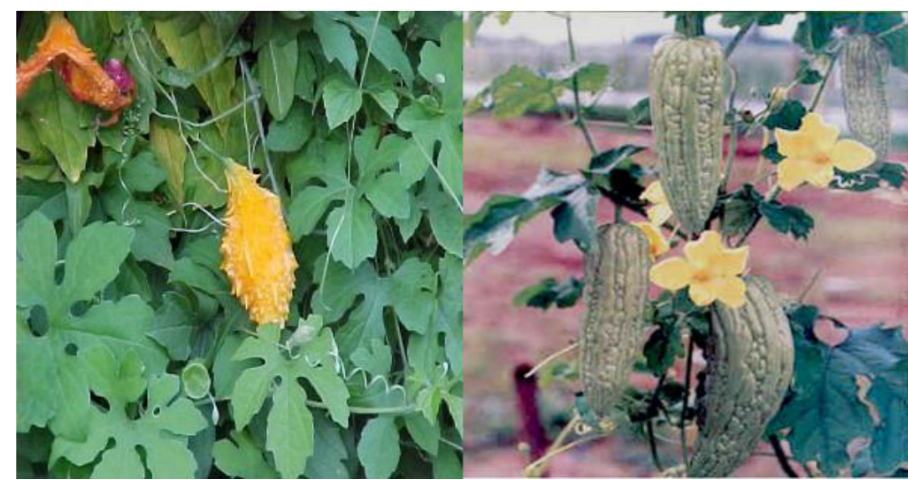

Figure 1: Photos F. J. A. Matos: Momordica charantia L. microcarpa (1- short fruits) and macrocarpa varieties (2- long fruits).

Horticulture of Medicinal Plants Prof. Francisco José de Abreu Matos from the Federal University of Ceara, in the period of flowering and fruiting. For the collection of the leaves was used pruning shears and for herborization were followed the usual procedures in this type of collection. ${ }^{17}$ The exsicates of Momordica charantia L. collected are deposited in the Herbarium Prisco Bezerra of the Federal University of Ceara under the numbers EAC31608, EAC31609, EAC16698 and EAC12887.

The studies were carried out with the fresh leaves of these two varieties of Momordica charantia L.

\section{Macro and Micromorphological Analysis}

The macromorphological analyzes were performed with the fresh leaves to the naked eye, proceeding to the general descriptions of each part, concomitantly, comparing the leaf characteristics of the M. charantia macrocarpa and microcarpa varieties.

For the micromorphological analysis, the leaves were cross-sectioned, which were fixed in $70 \%$ formaldehyde / acetic acid (FAA) for $48 \mathrm{hr}$ and later, stored in alcohol 70\%. Semi-permanent blades with section sections of $5 \mu \mathrm{m}$ were obtained from Leica 2065 microtome, clarified in $20 \%$ sodium hypochlorite, then washed in distilled water, bathed in acidified water and again in distilled water. ${ }^{18}$ The sections were stained with toluidine blue and analyzed using a Leica DM 4000B Led Optical Microscope and compared with the literature data. ${ }^{19}$

\section{Preliminary phytochemical approach}

For the accomplishment of preliminary phytochemical comparative analyzes between two varieties of $M$. charantia, microcarpa and macrocarpa, tests were carried out to determine groups of chemical substances common in plants, according to the methodology described by. ${ }^{20}$ All experiments were performed in triplicate.

\section{Obtaining Momordicine II}

Fresh leaves $(500 \mathrm{~g})$ of Momordica charantia L, microcarpa variety, were extracted by maceration in $1 \mathrm{~L}$ of ethanol $\left(96.5^{\circ} \mathrm{GL}\right)$ for $48 \mathrm{hr}$. The $50 \%$ ethanolic extract obtained was submitted to evaporation with the aid of a rotary evaporator. During this evaporation process, precipitation of off-white solid was observed. Thereafter, the procedure was interrupted and still in the flask, the supernatant alcohol phase was removed, to isolate the solid precipitate. This precipitate was washed successively with solvents of increasing polarities such as hexane, dichloromethane and acetone, to obtain a white solid encoded as (MSC). For the structural determination of this isolated substance (MSC), white amorphous solid, melting point $220-221^{\circ} \mathrm{C}$, we adopted a comparative analysis of MSC spectral data with those of momordicine I (Mo-1) and momordicine II (Mo-2), Table 2.
The one-dimensional and two-dimensional Hydrogen Nuclear Magnetic Resonance (NMR1H) and Carbon 13 (NMR13C) spectra were obtained on Bruker spectrometers, models DPX-300 and DRX-500, operating at a frequency of 300 and $500 \mathrm{MHZ}$ for hydrogen and 75. and $125 \mathrm{MHZ}$ for carbon 13, both belonging to the Northeastern Center for the Application and Use of Nuclear Magnetic Resonance (CENAUREN), from the Department of Organic and Inorganic Chemistry of the Federal University of Ceara.

The analytical procedure adopted, then, involved the comparison of the $\mathrm{NMR}^{1} \mathrm{H}$ (Nuclear Magnetic Resonance of Hydrogen) and $\mathrm{NMR}^{13} \mathrm{C}$ (Nuclear Magnetic Resonance of Carbon) of MSC, momordicine I (Mo-1) and momordicine II (Mo-2), interpreted with the contribution of two-dimensional (2D) spectra of heteronuclear correlation ${ }^{1} \mathrm{H}-{ }^{13} \mathrm{C}$ $\operatorname{COSY}^{-}{ }^{\mathrm{n}}{ }_{\mathrm{CH}}[\mathrm{n}=1$, HMQC (H-detected heteronuclear Multiple Quantum Coherence); $n=2$ e 3, HMBC (Heteronuclear Multiple Bond Connectivity)] e homonuclear ${ }^{1} \mathrm{H}-{ }^{1} \mathrm{H}$-COSY (Correlation Spectroscopy of hydrogen and hydrogen, scalar spin-spin interaction) and ${ }^{1} \mathrm{H}-{ }^{1} \mathrm{H}-\mathrm{NOESY}$ (Nuclear Overhauser and Exchange Hydrogen and hydrogen Spcetroscopy, dipole interaction promoted by spatial proximity), using deuterated pyridine $(\mathrm{C} 5 \mathrm{D} 5 \mathrm{~N})$ to obtain the spectra.

\section{RESULTS}

\section{Macroscopic and Microscopic Parameters}

The leaves of Momordica charantia L. of the macrocarpa and microcarpa varieties show the following common macroscopic characteristics: Are alternate, membranous, petiolate, orbicular limb, slightly toothed margin, obtuse apex and truncated base. They measure 6 to $12 \mathrm{~cm}$ in length and 8 to $12 \mathrm{~cm}$ in diameter, are multi-ribbed, with 5 to 7 angular lobes, separated by deep furrows. In both varieties, the upper face is slightly pubescent and the lower side is more densely hairy along the veins.

It was observed that the main differential macroscopic parameter between the leaves of the two varieties is that the leaves of the macrocarpa variety are larger than those of the microcarpa variety, as can be seen in the xeroexsicate (Figure 2). It is worth mentioning that the term and technique of xeroexsicates were elaborated by Professor Francisco José de Abreu Matos, this being a useful procedure to visualize the original morphological characters of the plant, which are often lost by drying the material after the preparation of conventional exsicata. It is the colored photocopy of the part of the plant to be studied. ${ }^{21}$

The micromorphological analyzes of the leaves of Momordica charantia L., macrocarpa and microcarpa varieties present the following common anatomical characteristics: the upper and lower epidermis consist of a

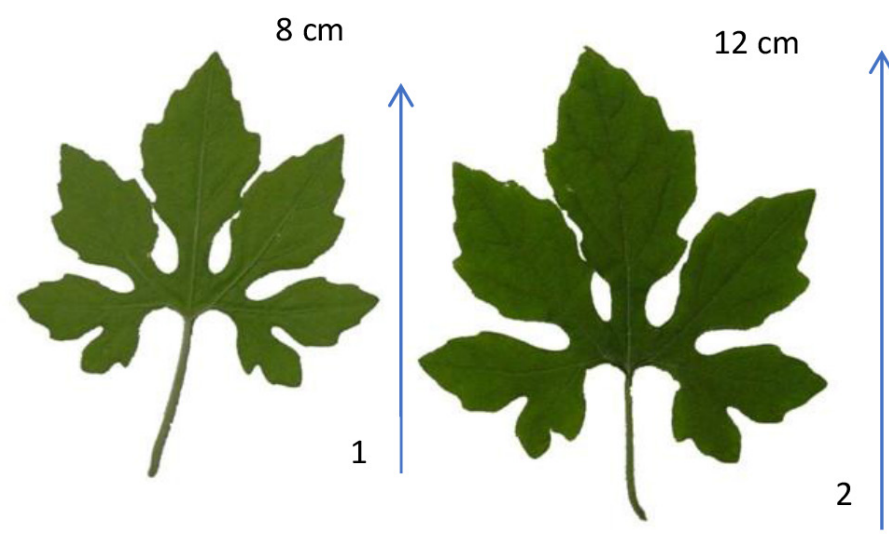

Figure 2: Xeroexsicate of the adult leaves of Momordica charantia L. microcarpa (1) $-8 \mathrm{~cm}$ and macrocarpa varieties (2) $-12 \mathrm{~cm}$. 
layer of polygonal cells. The mesophyll is narrow and compact, with few intercellular spaces. Its structure is dorsiventral, presenting palisade parenchyma constituted by a layer of elongated cells, of thin walls compactly arranged. The lacunar parenchyma is formed by several layers of cells of rounded to slightly elongated shape and looser arrangement. In the region of the midrib it is observed a single and small bicollateral bundle, immersed in parenchyma tissue. Below the epidermis occurs two layers of collenchyma, narrower on the adaxial side, as observed by. ${ }^{19}$ Rare short pedicled glandular hairs.

\section{Comparative Phytochemical Approach}

According to the results shown in Table 1, the phytochemical approach has shown that the two varieties have in common: alkaloids, steroids, triterpenoids, flavonoids, saponins, phenolic compounds, condensed tannins and flavonoids.

\section{Structural determination of MSC (momordicine II)}

The NMR1H spectrum of MSC showed signals for hydrogens of five methyl groups bonded to quaternary carbons $(\delta 0,94(\mathrm{~s}), 1,22(\mathrm{~d}, 7,8)$, $1,51(\mathrm{~s}), 1,21(\mathrm{~s}), 0,91(\mathrm{~s}))$; and two more of these methyl groups are attached to an olefinic carbon $(\delta 1.79(\mathrm{~s}), 1,71(\mathrm{~s}))$; three hydrogens linked to carbons with hydroxyls $(\delta 3,84(\mathrm{sl})$ and 4,38$)$, where one of which is adjacent to the olefinic hydrogen. it is observed a hydrogen bonded to a formyl group $(\delta 10,63)$ bonded to quaternary carbon, (Figure 3$)$.

The $\mathrm{NMR}^{13} \mathrm{C}$ spectrum showed signals for six quaternary carbons ( $\delta 43,21,147,14,52,03,47,35,49,72,133,66$ ), ten methyl carbons $(\delta 77,07,125,75,67,17,52,10,38,29,52,71,34,12,77,07,130,58)$, where among them is the aldehyde carbon in $\delta$ 209,27; seven methylene carbons $(\delta 23,20,29,26,24,14,31,07,36,38,31,38,31,34,45,2)$. It was observed the presence of carbons related to the $\beta$-Glucopyranosyl group ( $\delta 105,62,76,65,80,37,73,31,79,70)$, (Figure 4).

Table 1: Prospection of the chemical constituents present in the leaves of Momordica charantia L. macrocarpa (MCMa) and microcarpa (MCMi) varieties.

\begin{tabular}{ccc}
\hline TESTS & (MCMa) & (MCMi) \\
\hline Alkaloids & + & + \\
Anthocyanidins & 0 & 0 \\
Anthocyanins & 0 & 0 \\
Antranols & 0 & 0 \\
Aurones & 0 & 0 \\
Quaternary bases & 0 & 0 \\
Catechins & 0 & 0 \\
Chalcones & 0 & 0 \\
Cumarines & 0 & 0 \\
Steroids & + & + \\
Free phenols & + & + \\
Flavonoids & + & + \\
Cyanogenic heterosides & 0 & 0 \\
Leucoantocianidines & 0 & 0 \\
Resins & 0 & 0 \\
Saponins & + & + \\
Condensed tannins & + & + \\
Pyrogallics tannins & 0 & 0 \\
Triterpenoids & + & + \\
Xanthones & 0 & 0 \\
\hline
\end{tabular}

Caption: positive (+); negative (0).

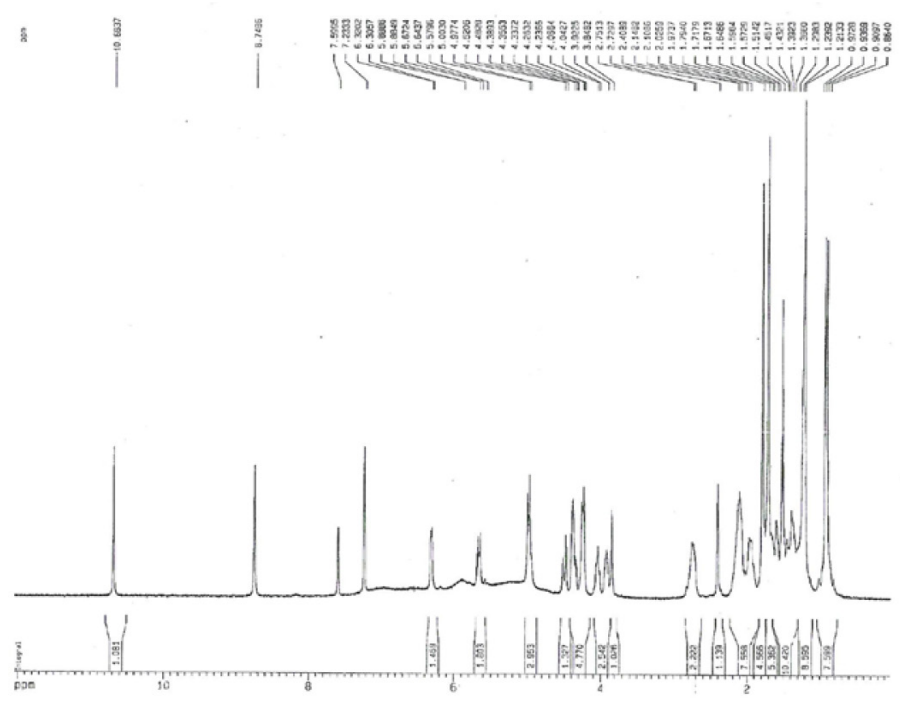

Figure 3: NMR1H of MSC compound in deuterated pyridine, momordicine II, present in the leaves of Momordica charantia L. microcarpa varieties (MCMi).

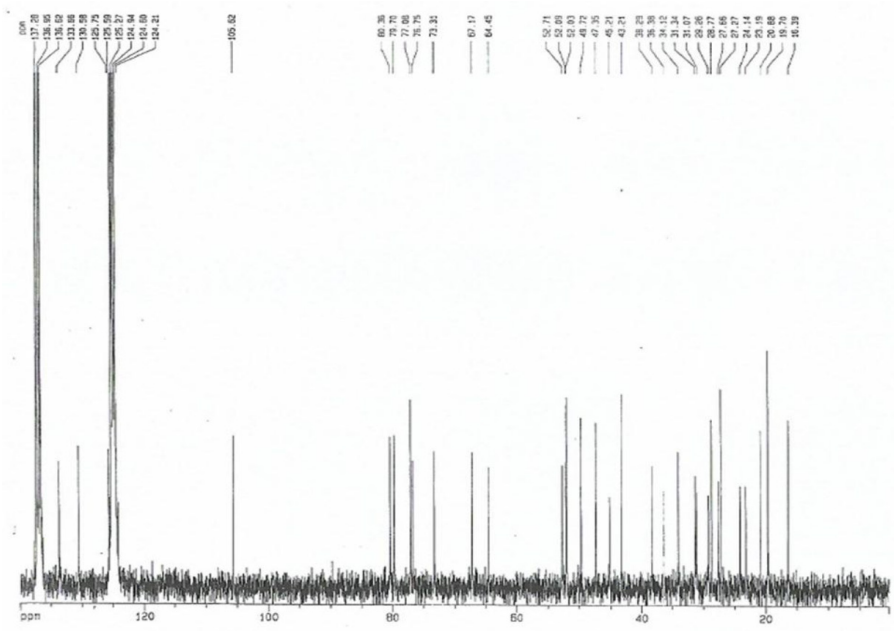

Figure 4: $\mathrm{NMR}^{13} \mathrm{C}$ of MSC compound in deuterated pyridine,momordicine II, present in the leaves of Momordica charantia L. microcarpa varieties (MCMi).

On Table 2 it's possible to see the comparison of the spectral data with of momordicine I (Mo-1) and momordicine II.

\section{DISCUSSION}

The knowledge about medicinal plants often is on result of the alternatives therapeutic resources of various communities and ethnic groups. In poorer regions and even large Brazilian cities, medicinal plants are commercializated in open markets, popular markets and found in residential yards. ${ }^{22}$

Many exotic vegetables are known for their biological properties. Bitter Melon (Momordica charantia L.), is a good example. This specie has nutritional and medicinal qualities and is commonly found in China, India and Africa. It is a flowering vine and contains an array of novel and bioactive phytochemicals..$^{23,24}$

The main differential parameter between the varieties is that in the macrocarpa variety the trichomes are less frequent and are of the short multicellular type with 3 to 5 cells, while those of the microcarpa variety are of the long multicellular type with 7 to 11 cells and are rarely starry. From the organoleptic characteristics of the analyzed leaves and stems, 
Guarniz, et al.: Pharmacognostic Evaluation of Momordica charantia L.

Table 2: Spectral data of NMR' $\mathrm{H}^{1}$ and $\mathrm{NMR}^{13} \mathrm{C}$ of MSC.

\begin{tabular}{|c|c|c|c|c|c|c|}
\hline & \multicolumn{4}{|c|}{$\mathrm{MSC}$, in $\mathrm{C}_{5} \mathrm{D}_{5} \mathrm{~N}$} & \multicolumn{2}{|c|}{ in $C_{5} D_{5} N$} \\
\hline & \multicolumn{2}{|c|}{${ }^{1} \mathrm{H}-{ }^{13} \mathrm{C}-\operatorname{COS} Y-{ }^{1} \mathrm{CH}_{\mathrm{CH}}$} & \multicolumn{2}{|c|}{${ }^{1} \mathrm{H}-{ }^{13} \mathrm{C}-\operatorname{COSY}-{ }^{\mathrm{n}} \mathrm{CH}_{\mathrm{CH}}$} & \multirow{2}{*}{$\begin{array}{c}\text { Mo-1 } \\
\delta_{c}\end{array}$} & \multirow{2}{*}{$\frac{\text { Mo-2 }}{\delta_{c}}$} \\
\hline & $\delta_{c}$ & $\delta_{\mathrm{H}}$ & ${ }^{2} \mathrm{~J}_{\mathrm{CH}}$ & ${ }^{3} \mathrm{JH}_{\mathrm{CH}}$ & & \\
\hline \multicolumn{7}{|l|}{$\mathrm{C}$} \\
\hline 4 & 43.21 & - & $3 \mathrm{H}-28 ; 3 \mathrm{H}-29$ & & 41.79 & 41.95 \\
\hline 5 & 147.14 & - & & H-7; 3H-28; 3H-29 & 145.73 & 148.30 \\
\hline 9 & 52.03 & - & $\mathrm{H}-8$ & & 50.61 & 34.41 \\
\hline 13 & 47.35 & - & $3 \mathrm{H}-18$ & $3 \mathrm{H}-30$ & 45.76 & 46.43 \\
\hline 14 & 49.72 & - & H- $8 ; 3 \mathrm{H}-30$ & $3 \mathrm{H}-18$ & 48.28 & 48.46 \\
\hline 25 & 133.66 & - & $3 \mathrm{H}-26 ; 3 \mathrm{H}-27$ & & 69.72 & 130.84 \\
\hline \multicolumn{7}{|l|}{$\mathrm{CH}$} \\
\hline 3 & 77.07 & $3.84(\mathrm{sl})$ & & $3 \mathrm{H}-28 ; 3 \mathrm{H}-29$ & 75.68 & 76.05 \\
\hline 6 & 125.75 & $6.31(\mathrm{~d}, 4.3)$ & $\mathrm{H}-7$ & H-8 & 124.29 & 121.03 \\
\hline 7 & 67.17 & 4.38 & $\mathrm{H}-8$ & & 65.73 & 72.55 \\
\hline 8 & 52.10 & 2.41 & & H-19; 3H-30 & 50.66 & 48.14 \\
\hline 10 & 38.29 & $2.73(\mathrm{~s})$ & & $\mathrm{H}-8$ & 36.90 & 39.29 \\
\hline 17 & 52.71 & 1.60 & & $3 \mathrm{H}-18 ; 3 \mathrm{H}-21$ & 50.15 & 51.34 \\
\hline 19 & 209.27 & $10.63(\mathrm{~s})$ & & & 207.81 & - \\
\hline 20 & 34.12 & 2.20 & $3 \mathrm{H}-21$ & & 36.58 & 32.99 \\
\hline 23 & 77.07 & 4.98 & & $\mathrm{H}-1^{\prime}$ & 124.23 & 65.31 \\
\hline 24 & 130.58 & $5.66(\mathrm{~d}, 8.6)$ & & $3 \mathrm{H} 26 ; 3 \mathrm{H}-27$ & 141.73 & 131.83 \\
\hline \multicolumn{7}{|c|}{$\mathrm{CH}_{2}$} \\
\hline 1 & 23.20 & $2.10 ; 1.75$ & & & 21.76 & 21.72 \\
\hline 2 & 29.26 & 1.50 & & & 29.94 & 30.12 \\
\hline 11 & 24.14 & $1.68 ; 1.60$ & & & 22.71 & 28.23 \\
\hline 12 & 31.07 & 1.97 & & $3 \mathrm{H}-18$ & 29.44 & 32.89 \\
\hline 15 & 36.38 & 1.40 & & $3 \mathrm{H}-30$ & 34.96 & 34.82 \\
\hline 16 & 31.34 & $2.10 ; 1.70$ & & & 27.75 & 30.65 \\
\hline 22 & 45.21 & $2.10 ; 1.25$ & & $3 \mathrm{H}-21$ & 39.56 & 45.51 \\
\hline \multicolumn{7}{|c|}{$\mathrm{CH}_{3}$} \\
\hline 18 & 16.39 & $0.94(s)$ & & & 15.05 & 15.64 \\
\hline 19 & - & - & - & - & - & 29.33 \\
\hline 21 & 20.87 & $1.22(\mathrm{~d}, 7.8)$ & & & 18.96 & 19.31 \\
\hline 26 & 19.70 & $1.79(\mathrm{~s})$ & & $3 \mathrm{H}-27$ & 30.85 & 25.79 \\
\hline 27 & 27.26 & $1.71(\mathrm{~s})$ & & $3 \mathrm{H}-26$ & 30.85 & $18.10 \mathrm{~b}$ \\
\hline 28 & 27.66 & $1.51(\mathrm{~s})$ & & $3 \mathrm{H}-29$ & 26.24 & 26.34 \\
\hline 29 & 28.77 & $1.21(\mathrm{~s})$ & & $3 \mathrm{H}-28$ & 27.39 & 28.38 \\
\hline 30 & 19.70 & $0.91(\mathrm{~s})$ & & $\mathrm{H}-8$ & 18.20 & $18.07 \mathrm{~b}$ \\
\hline \multicolumn{7}{|c|}{ Polysaccharides } \\
\hline $1^{\prime}$ & 105.62 & $4.99(\mathrm{~d}, 7.7)$ & & & - & 101.20 \\
\hline $2^{\prime}$ & 76.65 & 4.05 & H-3' & & - & 75.12 \\
\hline $3^{\prime}$ & 80.37 & 4.24 & & & - & 78.77 \\
\hline $4^{\prime}$ & 73.31 & 4.24 & & & - & 71.93 \\
\hline $5^{\prime}$ & 79.70 & 3.92 & & & - & 78.50 \\
\hline $6^{\prime}$ & 64.44 & $4.50(\mathrm{~d}, 11.3), 4.34$ & & & - & 62.82 \\
\hline
\end{tabular}


the bitter taste, the dark green color and the odor were similar in both varieties of $M$. charantia L.

In a phytochemical approach of the leaves of Momordica charantia L. microcarpa variety, ${ }^{19}$ reports not having detected the presence of alkaloids. It should be noted that the alkaloids detected in the present study were revealed with Dragendorff, Hager and Mayer reagents, highlighting the characteristic smoke odor in the extracts prepared for analysis, which may also contribute to the indication of the presence of this chemical class.

The comparison of the spectral data with those of momordicine I (Mo-1) and momordicine II (MO-2) leads to conclude that the substance encoded as MSC, $\mathrm{C}_{36} \mathrm{H}_{58} \mathrm{O}_{9}$, is the glycosylated tetracyclic triterpene ( $3 \alpha$, $7 \beta, 23]$ trihydroxy-cucurbite-5,24-dien-19a) -23-O- $\gamma$-glucopyranoside), whose common name is momordicine II, with similar structure to those found in plants of M. Charantia L. of Asian origin, by other authors. ${ }^{16,25,26}$ (Table 2).

The phytochemical tests performed in the present work revealed the presence of alkaloids, steroids, triterpenoids, saponins, phenolic compounds, condensed tannins and flavonoids in Momordica charantia L., Table 1. According to these results, the same secondary metabolites were found in fractions of M. charantia plant collected in northeastern Brazil. ${ }^{27}$ Silva, 2018 reports that tests performed on the collected species revealed the presence of flavonoids, tannins and alkaloids. In a phytochemical approach also from the leaves of Momordica charantia L., ${ }^{19}$ obtained positive results for the flavonoid, saponin, tannin and steroid / triterpene groups, but, contrary to the works cited, reports not having detected the presence alkaloids, which may be related to the collection time or some phytogeographic factor. ${ }^{28}$

\section{CONCLUSION}

The phytochemical approach, with the results of the characterization of similar chemical classes among the studied varieties of Momordica charantia L., as well as the identification of momordicine II, also in the microcarpa variety, reflect the chemotaxonomic relationship between the macrocarpa and microcarpa varieties. Because they are botanically distinct, it is necessary to continue studies to observe other parameters from the chemical and pharmacological point of view. The identification of momordicine II in the microcarpa variety is being reported for the first time in the literature. The information presented here also contributes to the importance of distinguishing these varieties when scientific articles are published with the species.

\section{ACKNOWLEDGEMENT}

We acknowledge Federal University of Ceara.

\section{CONFLICT OF INTEREST}

The authors declare no conflict of interest.

\section{ABBREVIATIONS}

CENAUREN: Northeastern Center for the Application and Use of Nuclear Magnetic Resonance; M. charantia: Momordica charantia; MQC: Multiple Quantum Coherence; NMR: Nuclear Magnetic Resonance.

\section{REFERENCES}

1. Duke JA, Bogenschutz-Godwin M, DuCellier J, Duke PA. CRC Handbook of Medical Herbs. Second edition. Boca Raton, FL: CRC Press. 2000;78-80. 1985;315-4.

2. Weebach MR, Murray MT. Botanical Influences on lillness. Tarzana, CA: Third Line Press. 1994;1399-41.

3. Grover J, Yadav S. Pharmacological actions and potencial uses of Momordica charantia: A review. J Ethnopharmacol. 2004;93(1):123-s32.

4. Lee-Huang $S$, Huangi $P$, Huang $P$, Bourinbaiar A, Hao-Chia $\mathrm{CH}$, Hsiang-Fu K. Inhibition of the integrase of human immunodeficiency virus (HIV) type 1 by anti-HIV plant proteins MAP30 and GAP31. Proc Natl Acad Sci USA. 1995;92(19):8818-22.

5. Seham B, El-Gengaihi S, Shabrawya O. Some toxicological studies of Momordica charantia $\mathrm{L}$. on albino rats in normal and alloxan diabetic rats. J Ethnopharmacol. 2006;108(2):236-42.

6. Nguyen N, Phan K, Chau M, Ninh B, Nguyen C, Nguyen T, et al. $\alpha$-Glucosidase Inhibition Properties of Cucurbitane-Type Triterpene Glycosides from the Fruits of Momordica charantia. Chem Pharm Bull. 2010;58(5):720-4.

7. Gupta S, Raychaudhuri B, Banerjee S, Das B, Mukhopadhaya S, Datta S. Momordicatin purified from fruits of Momordica charantia is effective to act as a potent anti Leishmania agent. Parasitol Internat. 2010;59(2):192-7.

8. Singh J, Cumming E, Manoharan G, Kalasz H, Adeghate E. Medicinal Chemistry of the Anti-Diabetic Effects of Momordica charantia: Active Constituents and Modes of Actions. The Open Medic Chem J. 2011;5 (Supple 2):70-7.

9. Zafar A, Manjeet S, Sharma P. Neuroprotective effect of Momordica charantia in global cerebral ischemia and reperfusion induced neuronal damage in diabetic mice. J Ethnopharmacol. 2011;133(2):729-34.

10. Yeh-Lin L, Yuh-Hwa L, Wen-Li L, Jong-Ho CH, Kur-Ta CH, Hong-Jen L, et al. Antibacterial and cytotoxic activities of different wild bitter gourd cultivars (Momordica charantia L. var. abbreviata Seringe). Botanic Stud. 2011;52(4):427-34.

11. Ullah M, Showkat M, Uddin N, Saiful I, Nurul A. Evaluation of Momordica charantia $\mathrm{L}$. fruit extract for analgesic and anti-inflamatory activities using in vivo assay. Res J Medic Plant. 2012;6(3):236-44.

12. Hyun $Y$, Seung $M$, Sanghyun L, Kye M, Eun J. The butanol fraction of Bitter Melon (Momordica charantia) scavenges free radicals and attenuates oxidative stress. Prev Nutr Food Sci. 2013;18(1):18-22.

13. Hsien-Yi W, Wei-Chin K, Tain-Junn C, Sung-Hsun Y, Liang-Hao C, Jiunn-Jye CH. Differential anti-diabetic effect and mechanism of action of charantin-rich extract of Taiwanese Momordica Charnatia between type 1 and type 2 diabetic mice. Food and Chem Toxicol. 2014;69:347-56.

14. Dandawate P, Subramaniam D, Padhye S, Anant S. Bitter melon: A panacea for inflammation and cáncer. Chin J of Natur Medic. 2016;14(2):81-100.

15. Svobodova B, Barros L, Calhelha R, Heleno S, Alves M, Walcott S, et al. Bioactive properties and phenolic profile of Momordica charantia L. medicinal plant growing wild in Trinidad and Tobago. Indust Crops and Prod. 2017;95:365-73.

16. Yasuda M, Iwamot M, Okabe H, Yamauchi T. Structures of Momordicines I, II and III, The bitter principles in The leaves and vines of Momordica charantia L. Chem Pharm Bull,. 1984;32(5):2044-7.

17. Instituto de Botânica (São Paulo). Técnicas de Coleta, Preservação e Herborização de Material Botânico. 1984;61. (Manual Nº4).

18. Oliveira F, Akissue G. Fundamentos de Farmacobotânica. Ed. Atheneu, São Paulo. 1993;216

19. Zocoler AMD, Mourão KSM, Mello JCP, Marques LC. Contribuição ao Controle de Qualidade Farmacognóstico das Folhas e Caules de Melão-de-São Caetano (Momordica charantia L. - Cucurbitaceae). Acta Farm Bonaerense 2006;25(1):22-7.

20. Matos FJA. Introdução a Fitoquímica Experimental. 3 ed, Editora UFC. 2009;150.

21. Matos FJA. Plantas Medicinais: Guia de seleção e emprego de plantas usadas em fitoterapia no nordeste do Brasil. Editora UFC. Fortaleza. 2007;365.

22. Soares F, Freire N, Souza T. Pharmacognostic evaluation and analysis of labels of the medicinal plants Boldo-do-Chile (Peumus boldus Molina) and Chamomile (Matricaria recutita L.), commercialized in Fortaleza, Ceará State, Brazil. Ver Bras Plant Medic. 2015;17(3):468-72.

23. Islam S, Jalaluddin M. Biological Functions and Sensory Attributes of Different Skin Colored Bitter Melon (Momordica charantia L.) Varieties. Am J Food Sci H. 2019;5(2):25-31.

24. Madala NE, Piater L, Dubery I, Steenkamp P. Distribution patterns of flavonoids from three Momordica species by ultra-high performance liquid chromatography quadrupole time of flight mass spectrometry: A metabolomic profiling approach. Rev Bras Farmac. 2016;26(4):507-13

25. Puspawati N. Isolation and identification momordicin I from leaves extract of Momordica charantia L. J Kimia. 2008;2(1):53-6.

26. Weng J, Bai L, Lin W. Identification of a Triterpenoid as a Novel PPAR $\gamma$ Activator Derived from Formosan Plants. Phytother Res. 2017;31(11): 1722-30.

27. Costa JGM, Nascimento EMM, Campos AR, Rodrigues FFG. Antibacterial activity of Momordica charantia (Curcubitaceae) extracts and fractions. J Basic Clin Pharm. 2011;2(1):45-51.

28. Silva CCDC. Análise fitoquímica e avaliação toxicológica do extrato de Momordica charantia frente ao microcrustáceo Artêmia Salina Leach. Universidade Federal De Pernambuco. 2018. 